\title{
Water Quality Assessment and Comparative Study of Coagulants and Flocculants with Different Dosages -A Review
}

\author{
Ms. P.M.Pathak ${ }^{1}$, Ms. A.A.Jadhav ${ }^{2}$, Mr. J.J.Chhajed ${ }^{2}$, Ms. P.K.Kshirsagar ${ }^{2}$, \\ Mr.S.A.Waghmare ${ }^{2}$ \\ ${ }^{1}$ Asst. Prof. Department of Civil Engineering, SAOE, Kondhwa, Pune-48 \\ ${ }^{2}$ Student, Department of Civil Engineering, SAOE, Kondhwa, Pune-48
}

\begin{abstract}
Water resources are equally important for natural ecosystem and human development. Rapid industrialization and indiscriminate use of chemical fertilizers and pesticides in agriculture are causing deterioration of water quality by varied pollution in aquatic biota. Due to use of contaminated water, human population suffers from water borne diseases. It is therefore essential to assist the quality of water at regular intervals of time. Parameters that may be tested include temperature, $p H$, and turbidity, hardness. The present review paper describes about the comparative study of water quality by using different dosages of coagulants and flocculants like Alum, Poly Aluminum chloride (PAC), Poly Electrolyte (PE) and combination of PAC+PE.

Keywords: Alum, PAC, PE, DO, PH, COD, Turbidity, TDS, TSS, NOM, BOD
\end{abstract}

\section{Introduction}

Water is the most widely distributed and abundant substance found in nature. From the total quantity of water present on the planet most of this water is not used for drinking purpose because $97 \%$ is present in the sea; means only 3\% is fresh water present, out of which $2 \%$ is in the form of polar ice caps and glaciers. Only $1 \%$ water is available for portable use. More water goes for irrigation than to drinking purpose and all other uses [WHO (World Health Organization) 2004]. The quality of water is an important concern for a human. History states that pollution of drinking water causes water borne diseases. Human activities induce influences on surface water quality, which include waste discharge directly into streams and also contaminated surface runoff. It is very essential and important to test the water before it is used for drinking, domestic, agricultural or industrial purpose. Water must be tested with

different physicochemical parameters. Selection of parameters for testing of water solely depends upon for what purpose water will be used and up to what extent we need its quality and purity. Water contains different types of floating, dissolved, suspended, microbiological and bacteriological impurities. Some physical test should be performed for testing of its physical appearance such as temperature, color, odour, $\mathrm{pH}$, turbidity, etc., while chemical tests should be performed for its BOD (Biochemical Oxygen Demand), COD (Chemical Oxygen Demand), DO (dissolved oxygen), alkalinity, hardness and other characters. It is obvious that drinking water should pass these entire tests and it should contain the required amount of mineral level.

Mismanagement of water resources has strong socio-economic repercussions, especially on food security and health. The extent of enteric diseases in different areas depends upon the extent to which certain water is exposed to contamination. World Health Organization (WHO) reports reveal that after installation of safe water pipes alone in 30 rural settlements of Japan, communicable intestinal diseases were reduced to $71.5 \%$ and that of trachoma by $64 \%$ while the death rate for infants and young children fell by $51.7 \%$.

The objectives of the present study were to analyze physicochemical and biological parameters of drinking water samples collected from the WTP to assess. Aluminum sulfate or alum is commonly used as a coagulant and seldom in waste treatment systems. In water treatment, it is used primarily for the removal of tiny particles called colloids, which are in the raw water measured as total suspended solids and too small to settle by gravity for a reasonable length of time. Although alum is the most established coagulant in water treatment, Moring oleifera (MO) seeds also known as malunggay can be used as an alternative coagulant.

\section{Literature Review}

1. N.B.Prakash, Vimala Sokan, P. Jayakaran (Mar 2014) carried out a study on "Waste Water Treatment by Coagulation and Flocculation". This experiment is done for the river water only. Coagulation and flocculation processes are used to remove suspended particles from water. As the suspended particles are negatively charged, the oppositely charged coagulant is added to mix with water in order to neutralize the particles. It will form flocs and due to increasing density of particles, it will settle down. Optimum pH based on turbidity was obtained as 7.0 and optimum alum dosage was noted as $120 \mathrm{mg} / \mathrm{L}$. Alum was found to be more efficient with removal percentage of 98.9 under an optimum condition. 
2. Arun K. Vuppaladadiyam, Sowmya V., Pallavi Dasgupta (2013) carried out “Comparative Study on Coagulation Process for Vellore Municipal Drinking Water Using Various Coagulants". Alum works best at $\mathrm{pH}$ 7.5 with an optimum dosage of $45 \mathrm{mg} / \mathrm{L}$ for the efficient removal of turbidity, total dissolved solids. Moringa oleifera seed extract does not prove to be an effective coagulant in terms of TDS, organic carbon and total coliform.

3. B.G. Mahendra, Madhusudhan C (Nov 2013) carried out "Comparative study on the performance of coagulants in water treatment". The characteristics of a water sample collected from river Bhima were found to be $\mathrm{pH}-7.28$, total solids $-496.25 \mathrm{mg} / \mathrm{L}$, alkalinity $-32.25 \mathrm{mg} / \mathrm{L}$ and turbidity $-155 \mathrm{NTU}$. Coagulant CM1 is found to be good coagulant for all the turbidity values with least dosage to remove $100 \%$ turbidity. CM1 has the wider range of $\mathrm{pH}$ suitability and works satisfactorily over a $\mathrm{pH}$ range of 5.0 to 9.0 over other coagulants considered for the study. The cost per unit weight of CM1 is less than both $\mathrm{C} 2$ and $\mathrm{C} 3$, but more than $\mathrm{C} 1$. The cost of coagulant required for treating 1 million liters of water is least for $\mathrm{C} 1$ even with its higher dosage requirement over CM1

4. Alexandra E.V. Evans, Yunlu Jiang, Munir A. Honjra, ManzoorQadir, Pay Drechsel (June 2014) carried out the study on "Water Quality: Assessment of the current situation in Asia". Water quality gets damaged due to generation of wastewater and inadequate treatment and management of the wastewater. Nearly $90 \%$ of untreated waste is pumped into the river in Asian countries as well as in another globe also. It is difficult to find out the particular problems in the certain region. Mekong River Commission is facilitating, monitoring across social boundaries. Population growth, waste management and urbanization in that particular region mostly affect the quality of water.

5. O.A. Ojo, S.B.Bakare, A.O. Babatunde (Dec 2009) carried out a study on "Microbial \& Chemical Analysis of Potable water in public water supply within Logas University, OJO". Chemical analysis of water includes the test of find out Alkalinity, Acidity, Total hardness, and $\mathrm{Ca} \& \mathrm{Mg}$ hardness. The $\mathrm{pH}$ was found as 5.5. The level of iron, calcium, and magnesium in circulating drinking water was found to be far below the WHO limits. In a laboratory of Logas experiments were carried out for isolation of E-coli, general coliforms, yeast. As the quantity of microbial in water increased, it will create spoilage and gives an adverse effect on the pipeline and other equipment.

6. Dr. N.C. Gupta, Ms. Shikha Bisht, and Mr. B.A. Patra carried out Physico-chemical analysis of drinking water quality from 32 locations in Delhi grown into a popular city. In this study, we collected 32 drinking water samples throughout Delhi. By using Indian Standards, different parameters were examined to find out their suitability for drinking purposes. During this examination mainly the physic-chemical parameters were taken into consideration.

7. Abraham Douglas. R. Cataylo and Maria Estephanie E. Leyva Carried out Comparative Study between MO seed and Aluminum sulfate on the Effect on $\mathrm{pH}$ and Turbidity Removal. Measuring its $\mathrm{pH}$ and the turbidity did an investigation of the effectiveness of the coagulant. He found that both MO and alum showed that they were equally effective in terms of turbidity. But in terms of $\mathrm{pH}, \mathrm{MO}$ was more preferred to alum. Thus, MO could be effective as compared to alum. The result showed that alum and MO seed coagulant lowers the initial turbidity of the sample water and for $\mathrm{MO}$; treated water is having $\mathrm{pH}$ in the range of 7-8. Thus, there is a need of the promotion of this coagulant as it is sustainable, appropriate and effective for water treatment.

8. Sneha S. Phadatare \& Prof. Sagar M. Gawande carried out Assessment of Seasonal Variation in Quality of Water Bodies. After the study of different research work, they conclude from the discussion that present scenario of the study area, reasons behind variation of parameters, quality of water, health issues arises or already present in study area also the remedial measures for less contamination. Water bodies taken for analysis purpose were checked for suitability in the form of drinking purpose and other utilities domestic use, agricultural use, industrial use, etc.

Physical and chemical properties of water as per IS 10500-2012

\begin{tabular}{|l|l|l|l|l|}
\hline S.No. & Parameter & Unit $\ldots$ & Accept. Limit & Permi. Limit \\
\hline 1 & Colour & Hazen Unit & 5 & 15 \\
\hline 2 & Odour & Platinum Cobalt Scale & Agreeable & Agreeable \\
\hline 3 & $\mathrm{pH}$ & $\mathrm{m}^{-}$ & $6.5-8.5$ & No relaxation \\
\hline 4 & Turbidity & NTU & 1 & 5 \\
\hline 5 & Total Dissolved Solids & $\mathrm{mg} / \mathrm{l}$ & 500 & 2000 \\
\hline 6 & Total Alkalinity & $\mathrm{mg} / \mathrm{l}$ & 200 & 600 \\
\hline 7 & Total Hardness & $\mathrm{mg} / 1$ & 200 & 600 \\
\hline 8 & & ${ }^{\circ} \mathrm{C}$ & $27^{\circ} \mathrm{C}$ & $27^{\circ} \mathrm{C}$ \\
\hline
\end{tabular}




\section{Conclusion}

All above impacts have resulted in the deterioration of water quality of river and lakes. The temperature variation is mainly related with the temperature of atmospheric and weather condition [3]. The reduction in the $\mathrm{pH}$ of River could have been due to the discharged industrial effluents. The increase in hardness can be attributed to the decrease in water volume in the rate of evaporation at high temperature, high loading organic substances, detergent, chlorides and other pollutants [1,5]. Minimum dissolved oxygen due to effluents discharge. Biological oxygen demand is an important parameter, which is widely used to determine the pollution load of waste water. The BOD test aimed is to determine the amount of bio-chemically oxidisable carbonaceous matter [4]. Chemical oxygen demand is a test which is used to measure pollution of domestic and industrial waste. This gives valuable information about the pollution potential of industrial effluents and domestic sewage $[22,24]$. Highest value of COD indicates that most of the pollution in study zone in River is caused by domestic effluents discharged by residential units. MO seeds can be used as an alternative coagulant, also called as natural coagulant. Hence, examination of water quality is necessary by different parameters mentioned above.

\section{Reference}

[1]. Agrawal A, Saxena M (2011). Assessment of pollution by physicochemical water parameter using regression analysis: A case study of Gagan River at Moradabad, India. Adv. Appl. Sci. Res. 2(2):185-189.

[2]. Azumi DS, Bichi MH (2010). Industrial pollution and heavy metal profile of Challawa River in Kano, Nigeria. J. Appl. Sci. Environ. Sanit. 5(1):2, 3-29.

[3]. CPCB, Guidelines for Idol Immersion, 2006. NewItem_159_Guideline_for_Idol_Imersion.pdf, accessed on 20th March, 2012.

[4]. Edema MO, OmenuAM, Fapeta OM (2006). Microbiology and physiological analysis of different sources of drinking water in Abeokuta. Nig. J. Microb. 13(1):57-61.

[5]. Eruola AO, Ufoegbune GC, Awomeso JA, Adeofun CO, Idowu OA, Abhulimen SI (2011). An assessment of the effect of industrial pollution on Ibese River, Lagos, Nigeria. Afr. J. Environ. Sci. Technol. 5(8):608-615.

[6]. Gupta A., Mishra K.., Kumar P., Singh C., and Srivastava S., (2011), Impact of religious Activities on The Water Characteristics Of Prominent Ponds at Varanasi (U.P.), India, Plant archives, 11(1), pp 297-300.

[7]. Gupta S, Bhatnagar M, Jain R (2003). Physico-chemical characteristics and analysis of Fe and Zn in tubewell water and sewage water of Bikaner City. Asian J. Chem. 15:727.

[8]. Nivedita Agrawal, Paras Mani Choubey and Dr. Jai PrakashPandey, "Water Quality Assessment of Baba Ghat of Bihar River Rewa (M.P.) ,” India International Journal of Scientific and Research Publications, Volume 4, Issue 10, October 20141 ISSN 2250-3153. :

[9]. Pande K. S. and Sharma S. D. (1998). Natural purification capacity of Ramgangariver at Moradabadișe. (U.P.). Poll. Res. 17, (4) : 409-415.

[10]. Pooja Tripathi, Virendra Kumar, Gyanesh Joshi, Sat Pal Singh, SureshPanwar, Sanjay Naithani, Raman Nautiyalișe: Study on Physico-Chemical Properties of ISSN : 2248-9622, Vol. 3, Issue,sEpi6, Nov-Dec 2013, pp.811-818. 272.

[11]. Rajgopal T, Thangamani A, Sevarkodiyone SP, Sekar M, and Archunan G (2010), Zooplankton diversity and physicochemical conditions in three perennial ponds of Virudhunagar district, Tamilnadu. J. Environ. Biol. 31:265-

[12]. Rajkumar, N. S., Nongbri B., and Patwardhan A. M., (2003), Physico-chemical and microbial analysis of Umiam (Barapani) lake water, Indian journal of environ. Prot., 23(6), pp 633-639.

[13]. Sanap RR, Mohite AK, Pingle SD, Gunale VR (2006). Evaluation of water qualities of Godawari River with reference to physicochemical parameters, district Nasik (M.S.) India. Pollut. Res. 25(4):775-778.

[14]. Tamot,P. and Bhatnagar, G.P., (1988), Limnological studies of upper lake Bhopal', S.K. Kulshreshtha, (ED.) Proceedings of national symposium, Past present and future of Bhopal lakes, pp 37-40. SLEF? 